\title{
Del marketing ecológico al greenwashing: una mirada en escenarios comerciales colombianos e internacionales
}

From Ecological Marketing to Greenwashing: a Look at Colombian and International Commercial Scenarios Do marketing ecológico ao greenwashing (lavagem verde): uma visão dos cenários comerciais colombianos e internacionais

Campo Elías López-Rodríguez Corporación Universitaria Minuto de Dios (UVD), Bogotá, Colombia. E-mail:clopezr3@uniminuto.edu.co

\author{
Luz Adriana Arévalo \\ Universidad ECCl, Bogotá, Colombia. \\ E-mail: larevaloz@ecci.edu.co
}

Fecha de recepción: 13/11/2018 Fecha de aceptación: 06/06/2019
Palabras clave

- Marketing ecológico

- Greenwashing

- Consumo responsable

- Mercados sostenibles

\section{Resumen}

El acercamiento hacia las tendencias actuales del marketing ecológico por parte de las organizaciones del siglo XXI debe ser una prioridad en su direccionamiento estratégico y, más aún, con el alto grado de responsabilidad que las empresas deben evidenciar en sus actividades comerciales y operativas en beneficio del medio ambiente y de la sociedad. Sin embargo, ha venido apareciendo un fenómeno que está perjudicando no solo a los consumidores, sino también a las empresas, su branding y a la marca país, y es el denominado greenwashing. Desde lo anterior y por medio de un estudio de caso, en este artículo se analiza el comportamiento de organizaciones que han evidenciado prácticas tanto de marketing ecológico como de greenwashing, afectando tanto positiva como negativamente a los consumidores, a las empresas y a la sociedad en general desde un escenario comercial colombiano y otro de carácter internacional. Los resultados aportan elementos de juicio tanto a la academia como al sector productivo desde el paralelo entre lo que el marketing ecológico y el greenwashing significan para la sociedad y la industria contemporánea. 
Keywords

- Ecological marketing

- Greenwashing

- Responsible consumption

- Sustainable markets

\begin{abstract}
The approach to the current trends in ecological marketing must be a priority for the strategic direction of $21^{\text {st }}$ century organizations, especially with the high degree of responsibility that companies should demonstrate in their commercial and operative activities for the benefit of the environment and society. However, there is a phenomenon that is damaging not only consumers but also companies, their branding and the country brand: it is called greenwashing. Based on this and through a case study, this article analyzes the behavior of organizations that have carried out practices of both ecological marketing and greenwashing, with both positive and negative effects on consumers, companies and society in general, from the perspective of a Colombian commercial scenario and another international one. The results provide elements to judge the academia as well as the productive sector regarding what ecological marketing and greenwashing mean for society and for the contemporary industry.
\end{abstract}

\section{Resumo}

A aproximação às tendências atuais do marketing ecológico pelas organizações do século XXI deve ser uma prioridade em sua direção estratégica, e ainda mais, com 0 alto grau de responsabilidade que as empresas devem demonstrar em suas atividades comerciais e operacionais em benefício do meio ambiente e da sociedade. Porém, tem surgido um fenômeno que está prejudicando não só os consumidores, mas também às empresas, sua marca e a marca país, o chamado greenwashing (lavagem verde). A partir do exposto e através de um estudo de caso, neste artigo analisa-se 0 comportamento de organizações que têm demonstrado práticas tanto de marketing ecológico quanto de greenwashing, afetando tanto positiva quanto negativamente os consumidores, às empresas e à sociedade em geral desde um cenário comercial colombiano e outro de caráter internacional. Os resultados fornecem elementos de julgamento, tanto para a academia quanto para o setor produtivo, a partir do paralelo entre 0 que 0 marketing ecológico e o greenwearsing significam para a sociedade e para a indústria contemporânea. 